\title{
Tocqueville and the American Presidency
}

\author{
HUGH BROGAN
}

In nothing is the difference between the Presidency today and in the nineteenth century more clearly symbolised than in the matter of accessibility. Today the President is closely guarded both for reasons of security and to save him from unreasonable calls on his time, and what is unreasonable is defined pretty strictly. For example, Mr. Walter Hickel, when he was Secretary of the Interior, found it impossible to get an interview with President Nixon on a matter he thought important. He took the desperate step of leaking his views to the press, and was dismissed for his pains.

Such an episode was inconceivable in the nineteenth century. Everyone knows the story of the reception at the White House on New Year's Day, 1863. So many people called to shake hands with Abraham Lincoln on that day, as was their right, that when he went upstairs to sign the Emancipation Proclamation he could hardly hold the pen steady. And everyone also knows the story of the riotous installation of Andrew Jackson in I 829 .

It was then considered highly un-republican, indeed dangerously aristocratic, for a President to seclude himself; and Jackson, whose predecessor, John Quincy Adams, and successor, Martin Van Buren, were both ferociously criticised for their airs and graces (Adams's crime was that he had installed a billiards table in the White House) was particularly careful to give no cause for offence. Indeed, his reputation for being an accessible President was an essential part of his political strength, as was to be shown when he admitted deputations of petitioners for relief, during the Bank War, and told them "Go to Nicholas Biddle! We have no money here, gentlemen. Biddle has all the money. ..." This message, repeated again and again, was rapidly carried over the country as the President's visitors dispersed to their homes, and did much to strengthen Jacksonian morale. Only when that was achieved did Hugh Brogan lectures in History at the University of Essex. An earlier version of this paper was delivered at the North American Studies Programme conference on the American Presidency at the University of Edinburgh on 26 April 1980.

Amer. Stud. 15, 3, 357-76 Printed in Great Britain 002 I-8758/8 I BAAS-3003 \$01.50 (C) I98 I Cambridge University Press 


\section{$35^{8}$ Hugh Brogan}

Jackson refuse to receive any more deputations, on the grounds that he was being deliberately misquoted. ${ }^{1}$

So it is no wonder that President Jackson had a regular day for receiving anyone who called; and on the afternoon of 19 January 1832 he played host to two young Frenchmen who were visiting Washington: Alexis de Tocqueville and his friend Gustave de Beaumont.

The occasion was pleasant enough. Jackson pressed a glass of Madeira on each guest, and they exchanged commonplaces for a little; but that was all. It is more than doubtful if Jackson ever gave his visitors another thought, while they were not much more impressed with him, or his house, or his office. The next day Beaumont, in the course of a letter home devoted to such topics as the cholera epidemic, his imminent return to France, his warm reception by the French minister in Washington, and his impressions of Congress, did fit in an account of his call on Jackson. The President, he said, was no genius, and owed his election solely to his military reputation, "so much is it the case that in all countries military glory has an irresistible prestige among the people, even a people made up of shopkeepers and tradesmen." His mansion was no more splendid than a noble family house in Paris; he kept much less state than a French minister would, but then the Presidency of the United States was a much more limited office than was supposed in France. ${ }^{2}$ Tocqueville, beyond noting the fact that it was no great thing to have your hand shaken by the American President, since he would shake anybody's hand, seems to have made even less of the occasion than Beaumont; though both young men were, in spite of themselves, a little impressed to find themselves addressing such a man as Andrew Jackson simply as "sir." 3 They were indeed a long way from the Tuileries.

This was one of Tocqueville's two great missed opportunities in his visit to the United States. The other was his inability to make a projected visit to former President Madison, which had to be foregone because winter conditions made the journey across the South much more time-consuming than expected and his leave from duty in Paris was running out. ${ }^{4}$ But Tocqueville at least got the best out of Madison by his long and careful reading of the

1 Arthur M. Schlesinger, Jr, The Age of Jackson (Boston, 1945), pp. I09-I I.

2 Gustave de Beaumont, Lettres d'Amérique, ed. André Jardin and G. W. Pierson (Paris, 1973), p. 210; see also, G. W. Pierson, Tocqueville and Beaumont in America (New York, 1938), p. 664.

3 Alexis de Tocqueville, Oeuvres Complètes, ed. G. de Beaumont (Paris, I866), Vol. 3 "Nouvelle Correspondance," p. I IO; Tocqueville to his father, 24 Jan. I 832. Some words have apparently been omitted from the passage dealing with the visit to the White House.

4 See Pierson, pp. 635-36. 
Federalist. ${ }^{5} \mathrm{He}$ never got, or made, anything much out of Jackson. The General did not put on one of his pyrotechnical displays of rage for him; and although Tocqueville read several of Jackson's public papers, he does not seem to have been much impressed by them; I cannot find that he read Jackson's Protest of 1834 , which contains the strongest and clearest exposition of Old Hickory's notion of the Presidency. Throughout Democracy in America Tocqueville underrated Jackson's significance, though he was obliged to refer to the General pretty often. More important, he never quite did justice to the Presidency itself.

His banal encounter with Andrew Jackson was hardly the entire reason. Tocqueville did not need to depend on the chances of drawing-room chit-chat to get a clear view of such an important topic as the Presidency of the United States; and in fact he did not. That was exactly the trouble: he went to the White House full of preconceptions. He remarked in the letter to his father already referred to, ${ }^{\circ}$

Just now Washington contains the most important men of the whole Union. We no longer seek instruction from them on subjects of which we are ignorant: instead we re-examine, in conversation with them, everything which we already know more or less. We settle the doubtful points....

Unfortunately, among the doubtful points was not the importance of the Presidency. The views that Tocqueville had formed before he got to Washington were those which he put in his book.

This can be easily demonstrated. Tocqueville's published estimate of Jackson differs only in length from Beaumont's verdict, already quoted:

Who dares deny the incredible influence that military glory has upon the mind of the common people? General Jackson, whom the Americans have twice chosen for their chief, is a man of violent temper and only middling ability; nothing in the whole course of his career having demonstrated that he had the necessary qualities for governing a free people, the greater part of the enlightened classes of the Union have always been opposed to him. What then has carried him to the presidential chair and now keeps him there? The memory of a victory he won twenty years ago before the gates of New Orleans; now, this victory of New Orleans was a most commonplace military feat which no-one would bother about for long except in a country which never fights any battles; and the people who have let themselves be thus carried away by the glamour of military glory are,

- "The Federalist is a fine book, which, although particular to America, ought to be familiar to the statesmen of every country." De la Démocratie en Amérique, Oeuvres Completes, ed. J. P. Mayer (Paris, I $66 \mathrm{r}$ edn.), I, i, I 16, footnote 7, all translations by the present author. This edition is henceforward referred to as $D A$. The influence of The Federalist is indeed all-pervading in the first volume of Democracy.

- See footnote 3 above. 


\section{6o Hugh Brogan}

beyond dispute, the coldest, most calculating, least military and, dare I say, the most prosaic of all nations.?

This was printed in 1835 . Yet it differs very little from a note he made during his visit to Baltimore in November, 1831 - two and a half months before he got to Washington. ${ }^{8}$

As an estimate of Jackson, this is plainly inadequate, and it does little justice to the battle of New Orleans either; indeed, coming from a member of a nation which was never able to beat Wellington's men, it is in rather poor taste. But it is easy to understand why, having formed this view, Tocqueville and Beaumont made no attempt to draw Jackson out on the subject of the Presidency.

Yet Tocqueville's views on that office, as expressed in Democracy in America, are neither unintelligent nor ill-informed. Time has amply vindicated some of them; at least we still endorse them today. There is Tocqueville on the effect of Presidential elections, for example:

Long before the appointed day arrives, the election becomes the chief, indeed one might almost say the unique, preoccupation of the public. The factions' ardour is redoubled; all the factitious passions that the fancy can stir up, even in a happy, peaceful country, erupt into the full light of day.

For his part, the President is entirely taken up with the cares of self-defence. He governs no longer according to the interests of the State, but according to those of his re-election; he prostrates himself before the majority, and often, instead of resisting its passions, as his duty requires of him, he hurries to anticipate its every caprice. ${ }^{\circ}$

These remarks seem anything but fresh today; but they do at least prove that Tocqueville saw and was interested in some of the problems of the Presidency that we see. (It is depressing that in all the years since 1835 so little should have been done effectively to solve them.)

It would be easy to summarise Tocqueville's views on the Presidency in such a way as to bring out only their good sense and accuracy. If instead I choose to approach the subject obliquely, by indicating what Tocqueville got wrong about the Presidency, it is partly because there is little point in para-

$7 D A, \mathbf{I}, \mathrm{i}, 290$.

8 "Ist November $183 \mathrm{r}$. Who dare doubt the pernicious influence of military glory in republics? What has led the people to choose General Jackson who, it appears, is a very mediocre man? What still guarantees him the votes of the people in spite of the opposition of the enlightened classes? The battle of New Orleans. And yet that battle was a most commonplace military feat, and the people who have let themselves be thus carried away are the most anti-military, the most prosaic, and the coldest of any in the world." Voyages, Ouevres Completes, ed. J. P. Mayer (Paris, 1957), 5, i, 186.

$9 D A, \mathbf{I}, \mathrm{i}, 137$. 
phrasing a man who wrote with such clarity and brevity, and one can have too much direct quotation. More important, if I stress the peculiarities of Tocqueville's presentation, it should be possible to bring out certain aspects of my two subjects - the Presidency, and Democracy in America - which another approach might blur.

Tocqueville's account of the Presidency of the United States takes up very little space in his great book: considerably more than does his account of Congress, but that is the best which can be said of it. ${ }^{10}$

Nowadays any author, setting out to give an account of the political character, customs and institutions of the United States, would feel obliged to make his description and analysis of the Presidency as long and detailed as his design and his publishers allowed. Everyone who has studied America knows how inexorably political, historical and social discussion turns to the Presidency; it is one of the most striking facts of American public life, and entails a host of important consequences. Nor is it a very new fact. Four strong men - Washington, the first Adams, Jefferson and Jackson - had all demonstrated the vitality, power and authority of their office before Tocqueville published his first volume. The mystique of the Presidency was already apparent, and its dynamic strength had been exhibited repeatedly. Washington had lent the office his own unique prestige, and had carried Jay's Treaty; Adams had made peace with France; Jefferson had purchased Louisiana and sustained the Embargo; Madison had survived the War of I812; Jackson had routed his political enemies in battle after battle. He had greatly extended the use of the veto power. He had effectively threatened South Carolina with war. He had dismissed all members but one of his Cabinet simultaneously (a record which remains unbroken). He had successfully defied Congress in the dispute about the status of the Secretary of the Treasury. He had launched the spoils system nationally by dismissing twelve hundred or so of the twelve thousand officials he found in office when he took power. He had appointed a leading supporter to the Chief Justiceship of the United States. He had lent his powerful patronage to the state of Georgia in its scheme to seize the tribal lands of the Indians within its borders, so that the Indians had appealed to the Supreme Court in vain. He had picked his own successor, and the year after Democracy in America appeared was to have the satisfaction of seeing that choice approved by the majority of the electorate. To sum it all up, he had demonstrated a new sort of political leadership. It was the clearest

10 As an institution, it gets eighteen pages in the Mayer edition of the Démocratie, out of a total, in the first volume alone, of four hundred and fifty-three. There is also some interesting material in the discussion of Jackson's Presidency $(D A, \mathbf{I}, \mathbf{i}$, 4IO-II). 


\section{Hugh Brogan}

possible demonstration of what the Presidency could be in active hands, and foreshadowed clearly what it might become; but Tocqueville was unimpressed. He notices several of the incidents I have listed; but his overall conclusion, repeated several times in various ways, is that the Presidency is a strikingly weak institution, especially in relation to Congress:

the President cannot forbid the passage of laws; he cannot evade his obligation to see to their execution. His zealous and sincere support for them is no doubt useful, but is not necessary for the carrying-on of government. In all essentials he is directly or indirectly subordinated to the legislature; where he is independent of it, he is almost powerless.... In Europe, agreement between king and parliament is necessary, because there can be a serious struggle between them. In America, agreement is not required, because struggle is impossible. ${ }^{11}$

General Jackson, we are told, is merely the slave of the majority. ${ }^{12}$

This sort of assertion would be impossible today, even to one who wanted to insist on the real limitations of Presidential power. It is tempting to say that Tocqueville should have known better, even in 1835 , and to let it go at that.

Tempting, but obtuse. Tocqueville arrived at his mistaken appreciation for many reasons; and one of them forces us to admit that in a way he was not mistaken at all. He compares the Presidency repeatedly with the monarchies of Europe, especially with the French monarchy of his own day; and by such a measurement there was indeed reason to say that the Presidency was weak. Tocqueville points out, for instance, that the French king disposes of 138,000 jobs, as against the President's paltry twelve thousand. Where the king was head of the government in a highly centralised state, the President was only the head of one branch of government in a highly decentralised federal structure. The French king could dissolve his parliament, make all the appointments to its upper house, and had an absolute veto on legislation: none of this applied in America. The king had lifelong, hereditary tenure: the President had, at most, two terms of four years each. The President could be impeached, the king could not. And so on. The list is formidable, and the line of reasoning, for an author who was above all trying to compel his French readers to think about their political institutions and society, inescapable.

This leads on to a second obvious point: that, as Tocqueville said himself, when he wrote of America, he thought of Europe; or, more precisely, of the implications of American democratic arrangements for the European democracy of the future; $;^{13}$ and it was therefore perfectly natural that he should, when discussing the Presidency, or indeed any other aspect of his

${ }^{11} D A, \mathrm{I}, \mathrm{i}, \mathrm{x} 29$.

$12 D A, \mathrm{I}, \mathrm{i}, 4$ IO.

$13 D A, \mathrm{I}, \mathrm{i}, \mathrm{I} 2$. 
subject, emphasize only those points which bore on his main theme, omitting others, and arranging his book accordingly rather than adopting the manner of a scholarly treatise on American government alone.

Democracy in America is a book of huge ambition, even if we leave out of account the second volume (not published until i 840 ). Tocqueville's account of his purposes, in the introduction, is too modest:

In the first part of this work I have, then, tried to show in what direction democracy, which in America is delivered up entirely to its inclinations and abandoned, almost unchecked, to its instincts, will lead the laws, and what course it will impress on the government, and in general what is the power which it exercises over public business. I wanted to know what were its good and evil consequences. I have enquired as to the precautions which the Americans employ to keep democracy under control, and as to those which they omit, and I have tried to establish what are the conditions which enable it to dominate society. ${ }^{14}$

Or, if not too modest, at least this summary is too dry. Democracy in America is a profound and thrilling meditation on modern history; its author concerned himself, not only with the march of equality, the decay of aristocracy, the power of the majority in the new world and its potential for tyranny, but with many minutiae of ordinary life, especially in its legal aspects; for he knew that no great historical or sociological hypothesis would be tenable for long which could not account for such details. His preoccupations emerge strikingly if one looks through the notebooks which he kept during his American journey. Certain subjects come up again and again, but they are not, or are only secondarily, governmental. The prospects of Catholicism sexual customs - race relations - slavery - Indians - education - land ownership - juries - the press - the class system - the West - roads - and, of course, prisons (he and Beaumont were, officially, visiting America in order to investigate them) - these, and a dozen other topics, figure at least as largely in his investigations as the state and federal governments. Rightly so: only on a foundation of such a nature could he hope to erect the new political science for an entirely new world that, he believed, was necessary. ${ }^{15}$ It was not to be expected that a man with such things on his mind should pay much attention to, say, the battle over the removal of the deposits during the Bank War. Democracy in America tries to depict the whole life of a people, and, at the same time, but distinctly, the necessary life of a democratic society; in such a project the place of close constitutional analysis must be limited. As it was, he managed to pack in an amazing amount of such analysis. But if we try to understand his principles of selection, of inclusion as well as exclusion, we soon come upon another reminder of his central purposes. For instance, he 14 Ibid. ${ }^{15} D A, \mathbf{I}, \mathrm{i}, 5$. 


\section{$364 \quad$ Hugh Brogan}

devotes a whole chapter to the question of whether or not a President should be re-eligible. He thinks not, emphatically not: the prospect of re-election will tempt the head of any government to use that government's power corruptly, and in America in particular the President enslaves himself to the majority which he ought rather to be guiding and guarding, if necessary against itself. ${ }^{16}$ It looks dry and speculative and, since the Americans had settled the question for themselves, redundant - until we remember that in I 848 Tocqueville was to have an important hand in drawing up the Constitution of the Second Republic, and that it was at his insistence and Beaumont's that the President was refused re-eligibility: ${ }^{17}$ the fatal provision which made the destruction of that Republic inescapable, for its first President, Louis Napoleon Bonaparte, rather than retire from power when his term was running out, staged a coup d'état. Looking at the chapter in Democracy in that light, we can see that Tocqueville guessed that France might one day be a republic (it had almost become one in 1830 ) and so felt it necessary to discuss a question that one day might have to be faced. Not until he wrote his Souvenirs (in $1850-5 \mathrm{I}$ ) did he admit, by implication, that he had come to the wrong conclusion. ${ }^{18}$

In this way it is also possible to interpret his remarks about Jackson as the slave of the majority, which seem so patently erroneous, and about the President's relations with Congress, which seem even worse. Consciously or not, Tocqueville is contrasting a democratic leader's alert attention to the wishes of his people with the dictatorial propensity of General Bonaparte and with the obstinate arrogance of Charles $\mathrm{X}$; and when he says that struggle between the American executive and legislature is impossible he has in mind such a struggle as that of the VIII Brumaire or that of the July Days of 1830 .

However, it cannot be denied that even when all allowances have been made a high residue of plain error confronts us. To take again the passage about Jackson and the majority: the annoying thing is that Tocqueville so very nearly gets it all right. His Jackson is a leader who is constantly studying his followers; who dares not attempt to be a despot; who wins influence and popularity by truckling to the all-powerful majority, in whose name he

${ }_{16} D A, \mathrm{I}, \mathrm{i}, \mathrm{r} 38-4$ o.

17 A. de Tocqueville, Souvenirs, Oeuvres Completes, Mayer edition; this volume edited by Luc Monnier (Paris, 1964), 12, 190.

${ }^{18}$ He does not, in the Souvenirs, mention the discussion in the Democracy; but the reasons he gives for thinking that he and Beaumont had been wrong in 1848 also apply to 1835 : "Our minds were not supple enought and quick enough to change in time and perceive that, from the moment that it had been decided that the citizens themselves should choose the President directly, the evil was irreparable, and would only be made worse by rash attempts to hamper the people in their choice." 
brushes aside Congressional obstruction. He is a Federalist by taste, a Republican by calculation; his popularity strengthens the federal government, but he will pass it on weakened to his successor; in his time,

the government of the United States tends to get weaker each day; it withdraws more and more from business, it perpetually narrows the scope of its actions. Naturally feeble, it gives up even the appearance of strength. ${ }^{19}$

Now this is excellent, so far as it goes; but it omits Jackson's skill in creating and energising the very majority to which he ostensibly deferred; it fails to see, or at any rate to mention, that he was largely animated by traditional Jeffersonian doctrine; and Tocqueville does not seem to realise that although Jackson deliberately weakened the federal government vis-di-vis the states, he equally deliberately strengthened the Presidency within the federal government. Van Buren inherited from Jackson both a formidably effective party machine and a rejuvenated Presidency; it was simply the bad luck of the Panic of 1837 and the depression of 1839 that disabled him. When in 1844 another Jacksonian President was elected, he soon showed what could still be done with Jacksonian instruments.

Tocqueville blundered: he approached the Presidency too much from a states' rights position, as well as with European preoccupations. He systematically played down the importance of the federal government and its components in favour of the states and the townships. Yet this blunder too is instructive: it throws light both on Democracy in America and on Jacksonian Democracy.

Had Tocqueville spent much time in the South, we might not be particularly surprised at his views, which were formed, moreover, at a moment when the great Nullification crisis was nearing its climax. He did, in fact, spend several days in conversation with Joel Poinsett of South Carolina, Jackson's chief troubleshooter in that state. But though they talked of America's maritime trade, of tariffs, of American sexual morality, of the nullification movement, the South, slavery, banking, roads, Mexico and even the Presidency, ${ }^{20}$ and Poinsett's influence on Tocqueville's ideas on all these points can be clearly seen in the relevant passages of Democracy in America, they did not discuss federalism, nationalism or states' rights. Tocqueville's views were shaped chiefly by his experience of New York, New England,

$10 D A, \mathbf{I}, \mathrm{i}, 4 \mathrm{I} \mathbf{I}$.

20 "Q. - Does the Presidential election stir up real political passions?

A. - No. It greatly excites those with something to lose or gain. It produces a frightful newspaper clamour. But most people remain quite indifferent to it. The President has so little real influence on public well being! It is Congress which actually governs." Voyages, 5, i, 150. 
and Ohio. He was making ready to investigate the South when the fatal summons home reached him. So it was the North which impressed Tocqueville so profoundly with the vigour of local government in America that he not only made decentralisation one of the pillars of his democratic faith, insisting on it in all his writings, but played down the federal government and minimised its nationalising tendency - and so, necessarily, played down the Presidency too.

Perhaps it was inevitable. Although Tocqueville had no very deep knowledge of French government when he arrived in the United States (he had to write home for information when he found he needed $\mathrm{it}^{21}$ ) he knew very well that he was the subject of a monarchy whose whole tradition was centralising, wide-ranging, indeed authoritarian. Louis Philippe was the heir of Napoleon, of the Committee of Public Safety, of Louis XIV. In spite of the great diversity of the French provinces (another American paradox which Tocqueville noticed was that Maine and Georgia, 400 leagues apart, were more alike than Normandy and Brittany) ${ }^{22}$, French government was rigid, uniform, Parisian. What was not done from the centre would not be done at all, whereas in the United States almost everything seemed to depend on local or individual initiative, and to depend successfully. Tocqueville was charmed, and over-impressed.

But it was only a mistake of degree. Everyone Tocqueville and Beaumont met insisted on the importance of local and regional self-government, and of course they were right. The truth is that it is too easy for us, today, to be impressed by the vigour of the Presidency, rather than by that of the states, when we look at Jacksonian America. We know too well that Jackson was creating precedents for Lincoln and the Roosevelts; we risk forgetting how intensely important the states were, not only in the South, to nineteenthcentury Americans. Tocqueville was not wrong when he fastened on the Erie Canal, built entirely by New York state, as a monument of great significance, showing the vigour and wide-ranging activity of the state governments. What is most striking about his remarks, though, is that he does not find it necessary to direct them against the idea that the federal government is all-important, the states', insignificant. He knows too much about American decentralisation to suppose such an argument necessary. Instead he directs his remarks against those who think that government in America believes wholly in laisser faire. Government in America, he says, has no pretensions to foresee everything and do everything; but very seldom does it abandon important works of utility to private enterprise. Look at the Erie Canal, at the canal joining Lake Erie to the Mississippi, at the canal ${ }^{21}$ Pierson, p. 403 .

${ }^{22} D A, \mathbf{I}, \mathbf{i}, \mathbf{1} 72$. 
joining Chesapeake Bay to the Delaware, and at the trunk roads system. ${ }^{23}$ This insistence on the importance of state governments seems to me wholly just, even though we know, as he did not, how many of the sort of enterprises he mentions were to end in bankruptcy. The states, having learned their lesson, left the next great public undertakings, the railroads, to be built by private capital; but even then, it scarcely needs to be said, the state governments remained deeply involved, if only in the business of soliciting and receiving bribes for charters, land grants, and so on, while the federal government directly subsidised the transcontinental railroads with land grants on the largest scale. All this surely reinforces Tocqueville's argument.

So I am inclined to argue that most of his sins of commission, when discussing the Presidency, are at worst venial, and often highly stimulating. His sins of omission are another story, and one of them was particularly serious. He failed to spot the meaning of the link between the Presidency and the party system. Yet it was all-important in American politics, and in making the smooth functioning of American democracy possible.

Even here, fairness obliges me to state that Tocqueville had many sharp and apposite things to say both about American parties and about the President's rôle in party politics: I have already quoted some of them. ${ }^{24}$ But he missed the essential; and this points not only to a defect in his understanding of the United States, but to one in his understanding of democracy.

For what Edward S. Corwin calls "Jackson's revolution" was going on under his nose, and he failed to notice it. This revolution consisted in part of a reversion to the old, Washingtonian conception of the Presidency, which Jefferson had replaced with his doctrine that the President was subordinate to Congress, his rôle merely to carry out the laws passed by that body. ${ }^{25}$ Notoriously, this was little more than a piece of Jeffersonian flattery: he had in fact a much tighter control of Congress than most other Presidents have enjoyed; but by 1829 it was received wisdom in most quarters. Jackson vigorously contradicted it, both in word and deed. In his view, as stated, for example, in his Protest to the Senate (I5 April I834) after that body had

23 Voyages, 5, i, $29 \mathrm{I}$.

24 Here is another example: "It is impossible to study the ordinary course of affairs in the United States without realising that the desire to be re-elected dominates the President's thoughts; that his administration's whole policy converges on this point; that insofar as the critical moment approaches, his individual interest prevails in his mind over the public interest." $D A, \mathbf{I}, \mathrm{i}, \mathbf{1} 39$.

25 Corwin makes this point, quoting Jefferson's first annual message as an example: "Nothing shall be wanting on my part to inform, as far as is in my power, the legislative judgement, nor to carry that judgement into faithful execution." E. S. Corwin, The President: Office and Powers, $4^{\text {th }}$ revised edition (London and New York, 1957), p. I8. 


\section{Hugh Brogan}

denounced him for having allegedly exceeded his Constitutional rights and powers,

each of the three great departments is independent of the others in its sphere of action, and when it deviates from that sphere is not responsible to the others further than it is expressly made so in the Constitution. In every other respect each of them is the coequal of the other two ... ${ }^{28}$

The key-word here is "co-equal". A doctrine is stated that most of us would nowadays take for granted, but that to Jackson's contemporaries was novel and rather shocking. They were not altogether wrong. We remember the story of the President's scornful remark after a decision of the Supreme Court had gone against him, "John Marshall has made his law; now let him enforce it." Corwin, who does not believe that anecdote, quotes a celebrated passage from the Bank Veto message:

The Congress, the Executive, and the Court must each for itself be guided by its own opinion of the Constitution. Each public officer who takes an oath to support the Constitution swears that he will support it as he understands it, and not as it is understood by others.... The opinion of the judges has no more authority over Congress than the opinion of Congress has over the judges, and on that point the President is independent of both.

Taken literally, this doctrine not only overthrows the practice of judicial review, but also makes it hard to see the point of having a written Constitution. Of course it is not to be taken literally. Jackson was only concerned to defend his novel use of the veto power, and, much more, to stir up public opinion to rally to his side in the war against Congress and the Bank. Any old stick would do to beat the dog with. But it is easy to see why his legalistic opponents (many of them informants of Tocqueville's) should cry usurpation, monarchy and tyranny. "I look upon Jackson as a detestable, ignorant, reckless, vain and malignant tyrant," said Chancellor Kent. "Though we live under the form of a republic we are in fact under the absolute rule of a single man," said Justice Story. "We are in the midst of a revolution," said Henry Clay, "hitherto bloodless, but rapidly tending towards a total change of the pure republican character of the Government, and to the concentration of all power in the hands of one man." 27 It was chiefly partisan froth, arising from the fact that the anti-Jacksonians could not over-ride the Bank Veto; but we must allow that there was a potential for executive usurpation, not just in Jackson's temperament, but in the doctrines he avowed. The controversy in our own day over "executive privilege" has its roots here, perhaps.

26 James D. Richardson, ed., A Compilation of the Messages and Papers of the Presidents, 1789-1897 (Washington D.C.: 1896ff), Vol. 3, p. 7r.

27 Quoted in Schlesinger, Age of Jackson, pp. ro6-07, 1 ro. 
On the whole, though, Jackson was merely restoring Presidential prerogatives to what they had been initially. The really original element in his view of the Presidency lay in his insistence on the democratic, tribunician aspect of the office; which indeed he may be said to have invented. "The President is the direct representative of the American people," he claimed. ${ }^{28}$

In Constitutional terms, this was a dramatic innovation. The Founding Fathers envisaged the indirect election of the President through the electoral college. Tocqueville was so impressed by this device that he wrote at length on the subject in Democracy, ${ }^{28}$ and tried in vain to have the President of the Second Republic chosen by indirect election in 1848 . Jackson, however, as was usual with him, attended to political realities rather than to constitutional fictions. He knew that the electoral college was a nullity, and that the House of Representatives, meant to be the democratic element in the system by the Founding Fathers, was riddled with sectionalism, personal ambitions and special interests. It could not think or speak for the whole American people. Whereas the President could and should: had he not been chosen by the majority of that people?

So much Tocqueville might have understood without difficulty; but behind these considerations lay another, to which he was, in the early 1830 , temperamentally and by upbringing, blind. For instance, when in 1837 he stood for election to the French Chamber of Deputies for the first time, he insisted on doing so as an independent, although the then Prime Minister, Comte Molé, who was his distant cousin and an admirer of the Democracy, offered him governmental support. Tocqueville spurned it, saying:

it is impossible for me to accept an official candidacy.... You are well aware, sir, that I am not opposed to this government in general, and particularly not to those who exercise its powers at this moment. But I want to be in a position to support it intelligently and freely; and I could not do that if I let myself be a governmental nominee. I am well aware that there are men who, on arriving in the Chamber, forget the means by which they got there; but I am not one of them. I want to get there while maintaining the position I propose to adopt there, and that position is an independent one..$^{\text {so }}$

This proud declaration was not quite what it seemed: Tocqueville was already inclining to the opposition; but it was not until after his election to the Chamber, which at length took place in 1839 , that he finally realised that independence was synonymous with ineffectiveness; and he was never to be happy as a party man. Beaumont has an excellent anecdote of the manner in

28 Richardson, Messages and Papers, 3, 90.

$29 D A, I, \mathrm{i}, \mathrm{I} 33-35$, "Mode de l'élections."

3o Tocqueville to Molé, I2 September 1837, Ouvres Complètes (Beaumont), Vol. 2, "Correspondance," pp. 74-75. 


\section{Hugh Brogan}

which, under the July Monarchy, Tocqueville associated with the party of the Left: “... I never could persuade him to be tolerably civil to them. Once, after I had been abusing him for his coldness to them, he shook hands with Romorantin, then looked towards me for my applause, but I doubt whether he ever shook hands with him again." ${ }^{31} \mathrm{He}$ was even farther from understanding, let alone accepting, the necessity of party, whether in $1831-32$, when he visited America, or in the years immediately following, when he was writing his book. At best he would concede that party was an inescapable evil. ${ }^{32}$

Jackson, on the other hand, well understood the value of party: none better. The President might claim to be the direct representative of the people, but he would convince only if he had been elected by them, not, as had happened in 1825 , by the House of Representatives. For in 1824 , when the general election was held, there were four leading candidates for the Presidency. Jackson was the most popular, but he did not have an overall majority either in the popular vote or in the electoral college; so the election was thrown into the House, which chose John Quincy Adams. Jackson never forgot this vexatious experience, and drew the correct moral: that to be sure of a sufficient majority a candidate must have an organisation to back him: in other words, a party. Just such an organisation was put together between 1825 and 1828 , in which latter year it won the first of three Presidential victories in a row. The thesis had been triumphantly proved. Jackson had created the circumstances which enabled him to claim to be the spokesman of the people.

The achievement was palpable; but Tocqueville missed it, largely because of his preconceptions about the nature of party, and especially of the American variety. There had once, he explained, been great parties in America. After the Revolution, "one of them wanted to restrain the power of the people, the other to extend it indefinitely." ${ }^{33}$ But following the victory of the Republicans in $1800-0 \mathrm{I}$, the Federalists, whose years of power had always rested on a somewhat artificial footing, split up and disappeared from view. By I831, when Tocqueville reached America, only small parties remained. Small parties, he explained,

are as a rule without a political faith. As they are not sustained and dignified by great purposes, their character is stamped with an egoism which is apparent in

31 Nassau Senior, Correspondence and Conversations of Alexis de Tocqueville, edited by M. C. M. Simpson (London, 1872), 2, 265. Tocqueville himself is brilliantly severe on his defects as a party man in his Souvenirs (pp. 102-04) - almost as severe as he is on other people.

32. "Parties are an evil which is inherent in free governments..." $D A, \mathbf{I}, \mathrm{i}, 178$.

ss Ibid., p. I79. 
all they do. They burn always, with a cold heat: their language is violent, but their progress is timid and uncertain. The means they use are as contemptible as the ends they set themselves. And so it comes about that when calm weather follows the revolutionary storm, great men seem to disappear and minds turn in upon themselves.

Great parties convulse society, small ones disturb it; the former tear it apart, the latter corrupt it; the former sometimes save it while shaking it, the latter only ever vex it to no good. ${ }^{34}$

Nowadays, he goes on, the United States is crawling with small parties, if only because "it is difficult to overturn the man in power, if your only reason is that you want his place," ${ }^{35}$ so ambitious men form parties to achieve the same end in the name of the common good.

A politician's skill, then, consists entirely in knowing how to put a party together: in the United States a politician first tries to discern his own interest and to see what analagous interests there are to group about it; next he exerts himself to find out if there may not be a doctrine or a principle, somewhere, which can plausibly be announced as the guiding light of the new association, thereby sanctioning its emergence and giving it currency.... That achieved, the new power is launched into the world of politics. ${ }^{36}$

It will be admitted by all students of Jacksonian America that there is something in this: one thinks of how Van Buren made his factitious hostility, one might almost say his perpetual paranoia, about moribund Federalism the justification of all his machinations to build up the Jacksonian party and secure its victory. Tocqueville goes on, equally shrewdly,

But a close study of the secret instincts that govern American factions quickly shows that most of them belong more or less to one or the other of the two great parties that have divided mankind since first there were free societies.... [A] ristocratic or democratic feelings can easily be discerned at the foundations of all parties.... ${ }^{37}$

And he goes on to give a brief account of the Bank War in terms of aristocrats against democrats, quite as if he were Arthur Schlesinger, Jr.

But even if the sketch has points of interest and accuracy, it is still only a sketch; one would not accept it, even as an outline, from an intelligent undergraduate, because of its gaps. For instance, as Richard P. McCormick has shown in detail, ${ }^{38}$ the emergence of the two-party system did more than anything else to break down mere sectional political divisions. After its establishment it did more than anything else to support national consciousness against the re-assertion of sectionalism. This was a well-advanced pheno-

34 Ibid., p. 179 .

36 Ibid., pp. I $81-82$.

35 Ibid., p. 18 r.

37 Ibid., p. I82.

38 Richard P. McCormick, The Second American Party System (Chapel Hill, I966). 


\section{Hugh Brogan}

menon in Tocqueville's day. Surely it merited investigation, the more so as he knew quite well how dangerous sectional loyalties could be. Indeed, in his chapter on parties he begins by remarking that

Some countries are so vast that the different peoples that inhabit them, although united under one sovereignty, have conflicting interests, from which is born a permanent opposition. In such a case the various segments of the one people do not form parties, properly so-called, so much as distinct nations; and if civil war should come about, it will be a conflict between rival peoples rather than a struggle between factions. ${ }^{39}$

And he goes on to contrast this state of affairs with a country where matters of equal importance to all parts of the country form the basis of division. These statements, linked with the many passages he devotes to slavery and the future of the Union, show how near he was to discovering the truth; but he never took the final step. Still less did he perceive the rôle of the Jacksonian Presidency in this process.

Implicit in Tocqueville's arguments, and occasionally explicit in his obiter dicta, is the belief that nowadays lesser men are competing for the high seats formerly occupied by the giants of the Revolution. (I am reminded of his remark about the contrast between the National Assembly of 1789 and that of 1848 : "then we had the cream of France, now we have only the skim milk." ${ }^{40}$ ) It is tempting to discuss whether John Quincy Adams was really, in any important sense, the inferior of his father, or Jackson the inferior of Washington; but leaving that aside, we cannot deny the importance of personal ambition in the early national period. We can, however, note, as Tocqueville failed to do, that however ignoble it was, at least ambition forced a man to look outside his own section for political support. Charles Wiltse, for example, has gone to infinite pains to show how slow, reluctant and agonising was Calhoun's retreat from the posture of a national statesman to that of spokesman for a section. ${ }^{41}$ Even that notoriously divisive man, Abraham Lincoln, was a sectional candidate in a very special sense: in the previous generation a man who could win majority support in New England, the Old Northwest, the Pacific coast, and the middle Atlantic states would have been held up as the very opposite of a sectional candidate. Even in I 860 he was a sectional candidate only in the sense that he failed to carry a single slave state. And even in 1860 all the candidates, including Lincoln, were picked with their trans-sectional appeal in mind. Seward was rejected by the Republicans because they thought his candidacy would put off conservatives in the Border states and elsewhere. Bell and Breckinridge both

$39 D A, \mathbf{I}, \mathrm{i}, \mathbf{1} 78$.

to Senior, Conversations, i, 44 .

$\$ 1$ Charles M. Wiltse, John C. Calhoun (Indianapolis, 3 vols., 1944-1951). 
came from Border states, although Breckinridge was the preferred candidate of the slave South. Douglas, in his finest hour, stumped the entire country, and spoke, like Webster ten years previously, for his cause - the Union. True, the national appeal failed; but just as we cannot overlook the value of the Presidency as a standard to which the United States could rally in the Civil War which followed (or for that matter in every other war), so we should not forget that in 1860 it was the last national institution which had a chance to keep the nation together; and it was the ordinary ambitions of political men which ensured that the chance was not overlooked.

The Presidency not only put the ambitions of the great to useful work; it did the same for lesser mortals. Those twelve thousand offices stimulated the office-seekers to look beyond their own towns and states for satisfaction, and to create national organisations. And it gave great scope for the art of leadership, the sort of leadership which turbulent, loose-jointed, widespread, underpopulated America badly needed.

It would be absurd to blame Tocqueville for failing to see all this; nor is it very important to account for his failure. The reasons are fairly obvious. He took most of his views from anti-Jacksonians, who relied on the states and on Congress to cut the President down to size. ${ }^{42} \mathrm{He}$ disliked charismatic leadership, well knowing what, as exercised by Napoleon, it had cost France; most of all, he remembered the great strife of parties in the French Revolution, and what had been at stake in their struggles. No wonder that he was not much impressed by the machinations of the Americans.

Yet we can see what he could not: that the Presidency is a dynamic power in American politics, and its energising principle. A central problem of democracy, as of any political system, must after all be that of survival by successful adaptation and by intelligent application to problems. The Presidency is the instrument which the American people use for this essential purpose. And the Presidential contest, by polarising, imposes order on American politics, and through that order ensures the continuous working of the constitutional system. While there is party politics there is hope, and without hope any state totters. This is surely an important practical truth, which needs to be assimilated in any rationale of any democratic system if it is to succeed. It is a pity that Tocqueville did not understand this. My last argument concerns the consequences of his failure.

It did not occur to him that the Presidency was the most remarkable of American political innovations, that the device of an elective republican

42 For instance, the account of American political parties which appears in the Democracy (1, i, 178-82) was very largely inspired by a conversation with Nicholas Biddle, of all people. See Voyages, 5, i, 1 22-23. 


\section{Hugh Brogan}

monarchy would be the most widely copied of American political institutions. Collective leadership, of one kind or another, seemed to be the liberal norm in the West, and Tocqueville did not see the Presidency as the portent of something new. It is worth recalling that he knew very little about British politics at the time when he wrote the first volumes of the Democracy, and nothing about the office of Prime Minister, which in its way was as portentous as the Presidency for the future of democratic government. Nor did he see Louis-Philippe as a presidential, democratic leader: rather he saw him, as Louis-Philippe so unfortunately saw himself, as the latest of the forty kings of France (it is usually forgotten that he was not the first "King of the French" - that had been Louis XVI's title also under the Constitution of I790). By instinct, I think, Tocqueville was a republican after I 830 since it no longer made sense to be a legitimist; which perhaps explains, as I have already suggested, why he thought the question of Presidential re-eligibility so important; but his notions of what a French republic ought to be were, at the organisational level, thoroughly rudimentary. He had much less flair in this respect than Lamartine, whom he so much despised; and of course he denied his instinct and clung to the device of a constitutional monarchy throughout the period from 1830 to 1848 . His old-fashioned approach explains, perhaps, the disastrous failure of the 1848 constitution, which, while affecting to copy the Constitution of the United States and establishing a Presidency, really re-established the French monarchy for the third or fourth time since 1792 . The Second Republic failed because it was neither genuinely parliamentary nor genuinely presidential: instead of giving France a system which was both democratically accountable and democratically dynamic, it re-staged the old deadlock between executive and legislature which had brought down so many regimes in the recent past.

In this respect at least Tocqueville's generation learned their lesson, after instruction by Louis Napoleon and Marshal MacMahon, and under the Third Republic the Presidency was largely an honorific post, answerable to the National Assembly. Thus Tocqueville's desire for indirect election of the head of state was at last achieved. It was not until 1958 , nearly a century after Tocqueville's death in 1859 , that General de Gaulle gave France her first truly Presidential, American-style regime (and even the constitution of the Fifth Republic originally prescribed indirect election for the Presidency: not until he had settled the Algerian question did De Gaulle introduce direct election for the job).

If Tocqueville failed to grasp the full significance of the Presidency, it was inevitable, as we have seen, that he would fail to grasp the significance of that closely related device, the political party. He never understood its 
legitimacy; he felt distaste for almost all its manifestations. One curious result of this weakness was that when he became a politician he chose his associates badly. As he shows himself bitterly aware in the Souvenirs, after the event, the men he worked with, as much as the men he worked against, helped to destroy all possibility, for their time, of a stable French state. Barrot, Thiers and Cavaignac were wreckers as much as Louis Napoleon and Blanqui; infinitely more so than Lamartine. Their only concern was for the final victory of their party, to the exclusion of the men, interests and programme of their opposition. The great revolutionary battle of the factions resumed; the issue was always the future of the regime, when it was not war or peace. For years after Tocqueville's death the miserable cycle of revolution, conspiracy, coup d'état and foreign invasion would revolve. It would be nice to believe that at some stage he came to realise that there was much to be said for the spayed contest of an American presidential election; but there is no evidence that he ever did. On the contrary, as late as the Ancien Regime $(1856)$ it is clear that he still under-rated the problems and importance of political leadership. At any rate, it has been plausibly suggested that one of the failings of that book is its scanty treatment of the part played by Louis XVI and his ministers in the coming of the Revolution.

These omissions and imperceptions are all evidence of a larger failing: Tocqueville did not have a theory of political leadership. Any explanation of this great lack must, to be adequate, take account of several factors. The psycshological: brought up in the restricted circles of a close-knit, aristocratic family, Tocqueville was temperamentally too fastidious, too much the gentilhomme, for the vulgarities of mere politics. The historical: the most effective recent examples of popular leadership in French history, from La Fayette to Thiers, filled him with alarm. He associated them with revolution and war, the two supreme enemies of that liberty which was his supreme goal. The ideological: it had long been liberal dogma that in a free society the representative assembly should be supreme. So Tocqueville could only see the assertive Presidency of Andrew Jackson as at best an aberration; at worst, as a reminder of the eternal threat of usurpation and dictatorship. The accidental: the circumstance that Andrew Jackson was not in an expansive mood that January afternoon at the White House. 